Review

\title{
Long Non-Coding RNAs and the Innate Immune Response
}

\author{
Marina R. Hadjicharalambous * and Mark A. Lindsay \\ Department of Pharmacy and Pharmacology, University of Bath, Claverton Down, Bath, BA2 7AY, UK; \\ mal37@bath.ac.uk \\ * Correspondence: mh939@bath.ac.uk or m.hadjicharalambous@bath.ac.uk; Tel.: +44(0)1225384435
}

Received: 25 March 2019; Accepted: 17 April 2019; Published: 19 April 2019

\begin{abstract}
Innate immunity provides the initial defence against infection and it is now clear that long non-coding RNAs (lncRNAs) are important regulators of this response. Following activation of the innate response, we commonly see rapid induction of these lncRNAs and this is often mediated via the pro-inflammatory transcription factor, nuclear factor- $\mathrm{kB}$ (NF- $\mathrm{kB}$ ). Knockdown studies have shown that lncRNAs tend to act in trans to regulate the expression of multiple inflammatory mediators and other responses. Mechanistically, many lncRNAs have demonstrated acting through heterogeneous nuclear ribonucleoproteins, complexes that are implicated chromatin re-modelling, transcription process and translation. In addition, these lncRNAs have also been shown to interact with multiple other proteins involved in the regulation of chromatin re-modelling, as well as those proteins involved in intracellular immune signalling, which include NF- $\mathrm{kB}$. In this review, we will describe the evidence that supports this emerging role of lncRNA in the innate immune response.
\end{abstract}

Keywords: long non-coding RNA; lncRNA; innate immunity; inflammation

\section{Introduction}

Long non-coding RNAs (lncRNAs) are generally defined as endogenous cellular RNA molecules of more than 200 nucleotides in length that lack an open reading frame (ORF) of significant length (less than 100 amino acids) and contain 2 or more exons [1,2]. They were originally discovered in mice during large-scale sequencing of full-length cDNA libraries as part of the FANTOM project [3]. Currently there are 16,066 lncRNA genes and 29,566 lncRNA transcripts documented in the human genome database (version 29) of GENCODE, compared to 19,940 protein coding genes [4]. Accumulating sequencing data has meant that the number of IncRNAs continues to increase, including some that were previously mistakenly identified as protein coding genes [5].

As with protein-coding genes, the majority of IncRNAs appear to be transcribed by RNA polymerase II (RNAPII) [6], although there are a few exceptions that are transcribed by RNA polymerase III (RNAPIII) including the 7SL RNA genes [7]. LncRNAs have also been shown to be subjected to transcriptional editing such as splicing, polyadenylation and $5^{\prime}$ capping [6]. Subsequently, each lncRNA develops a final stable structure which shapes its unique cellular function, enabling it to interact with other molecules [8].

Despite the rapid increase in data relating to lncRNAs, little is known regarding their exact functions, mechanism of action or even how many different types of lncRNAs exist. Even though lncRNAs generally demonstrate poor evolutionary conservation [9], it is evident that they play important roles in multiple biological pathways, including modulation of the innate immune response [10,11]. 


\section{Characteristics of lncRNAs}

LncRNAs present several distinct characteristics when compared to mRNAs regarding their size, specificity, organisation and subcellular localisation. However, despite the differences, they also possess a lot of similarities to mRNAs regarding their biogenesis and form.

\section{LncRNAs and mRNAs Share Similar Biogenesis Pathways}

LncRNAs are predominantly transcribed by RNAPII and most are spliced, polyadenylated at the $3^{\prime}$-end, $5^{\prime}$-end capped with 7-methylguanosine and are associated with similar histone markers to those of mRNAs $[6,12,13]$. Non-polyadenylated lncRNAs, including those associated with enhancer regions [14], are thought to be stabilised through other mechanisms. These include ribonuclease P (RNase P) cleavage to generate mature 3 '-ends, the formation of circular molecular structures such as circRNAs or capping by small nucleolar ribonucleoproteins (snoRNP) complexes [15,16]. Unlike mRNAs which are known for their protein coding functions and translational potential, lncRNAs lack an ORF of significant length and quality [13] and are therefore deemed to have no translational capacity. However, interestingly, a study by Ruiz-Orera et al. suggested that lncRNAs may give rise to small novel peptides [17].

\section{LncRNAs Are Expressed at Lower Levels Compared to mRNAs}

LncRNAs are generally shorter in length, have fewer, but longer exons and are expressed at lower levels compared to mRNAs [13,18,19]. Indeed, lncRNAs demonstrated lower expression in all tissues compared to mRNAs except in the testes where they showed tissue-specific elevated expression levels $[9,18,20,21]$. These lower expression levels were initially advanced as evidence that lncRNAs were simply the result of transcriptional noise. This has since been disproved, following evidence showing biological functionality.

\section{LncRNAs Expression Is Cell and Tissue Specific}

Transcriptome-wide studies demonstrated that expression of lncRNAs is specific for the cell, tissue, developmental or disease state, as well as highly dependent on context and time $[13,18,20,22]$. For example, Cabili et al. found that $78 \%$ of lincRNAs were tissue-specific across 24 tissue and cell types compared to approximately 19\% of protein coding genes [18]. This specificity of lncRNA expression may explain their low levels of expression compared to mRNAs and indicates that they possess cell/tissue selective functions [23].

\section{LncRNAs Show Poor Evolutionary Conservation}

Unlike protein coding genes, lncRNAs generally show poor evolutionary conservation $[9,13,18]$ and this lack of sequence conservation has made it difficult to identify functional domains and to compare their biological significance across species [24]. In general, the exon regions of lincRNAs were shown to demonstrate higher conservation than random un-transcribed intragenic regions, although still considerably less than that observed in exon regions of protein coding genes. Interestingly, the conservation across the promoter regions of lncRNAs is comparable to that of protein coding genes [6,25]. This lack of conservation appears to be related to the rapid evolution of lincRNAs, most lincRNAs have no conserved orthologues [19]. In contrast to sequence conservation, thousands of lncRNAs were found to demonstrate highly conserved genomic positions (synteny) [26]. Despite the general observation of poor conservation, a small number of lncRNAs demonstrate high conservation at both the sequence and structure levels and include well-characterised lincRNAs such as MALAT1 (metastasis associated lung adenocarcinoma transcript 1) and NEAT1 (nuclear enriched abundant transcript 1) [27].

\section{Subcellular Localisation of lncRNAs}

After transcription in the nucleus, mRNA transcripts tend to be transported to the cytoplasm where they undergo translation. In contrast, lncRNAs are found both in the nucleus and the cytoplasm, 
although current evidence suggests that they are predominantly enriched in the former $[13,28]$. Nuclear lncRNAs include some of the best studied lncRNAs such as NEAT1 [29], MALAT1 [30] and XIST (X-inactive specific transcript) [31] where they are thought to regulate epigenetic modifications and mRNA processing. However, even though lncRNAs as a group are more enriched in the nucleus compared to mRNAs, cytoplasmic lncRNAs are reported to be expressed in higher numbers [22,32]. Interestingly, a report by van Heesch et al. [33] showed a 30\% enrichment of lncRNAs in the cytoplasm and $38 \%$ in ribosomal fractions compared to just $17 \%$ in the nucleus. Additionally, ribosome-profiling experiments have found abundant numbers of lncRNAs associated with ribosomes, suggesting they may actually be translated $[17,34]$. However, further studies failed to detect protein products from the supposed translation of lncRNA ORFs, suggesting that ribosomes can distinguish between coding and non-coding transcripts, and concluding that lncRNAs are unlikely to encode peptides/proteins [35].

\section{Classification of lncRNAs}

A convenient way to classify lncRNAs is based upon their position relative to well-established markers such as protein-coding genes (Figure 1). However, several lncRNAs do not fit into any of these categories as they present a combination of these qualities or they cover long genomic distances [36]. The most significant lncRNA classes are discussed below.

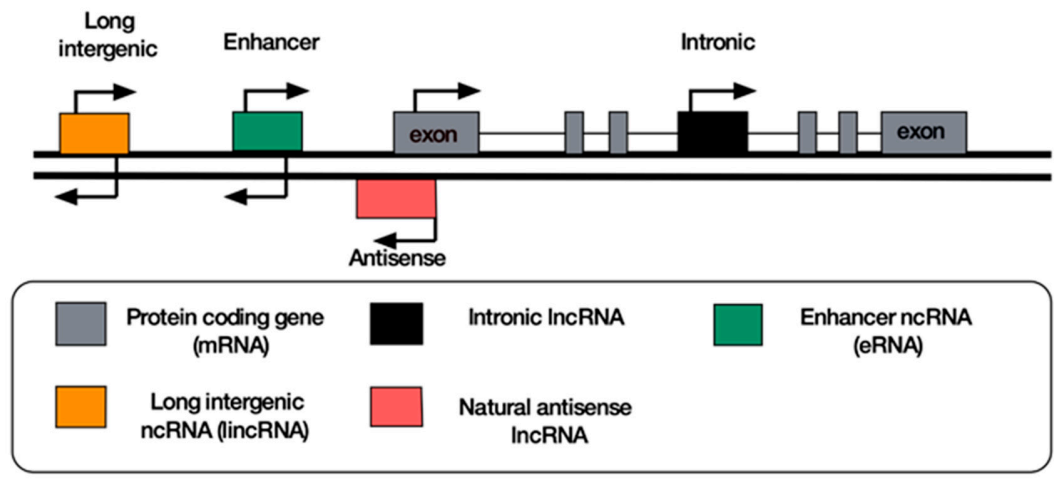

Figure 1. Classification of the most widely found lncRNAs according to their genomic location. Attempts to resolve the transcriptomic complexity of lncRNAs have led to their classification based on their genomic proximity to protein coding genes (mRNA). LincRNAs and eRNAs are stand-alone transcription units situated near protein coding genes. Intronic lncRNAs are found within the introns of protein coding genes, while antisense lncRNAs are transcribed from the opposite strand from the exonic regions of protein coding genes.

\section{Antisense lncRNAs}

Antisense lncRNAs, also known as natural antisense transcripts or NATs, are transcribed across the exons of protein-coding genes from the opposite strand, with varying degrees of overlap from partial to complete. Gene regulation by antisense transcripts occurs mainly in cis [37], where the antisense lncRNA interacts with its associated or neighbouring genes. GENCODE currently lists 5587 antisense lncRNA genes and 11,443 transcripts [4]. Interestingly, it is suggested that as much as $70 \%$ of protein coding genes have antisense counterparts [38,39].

\section{Long Intergenic Non-Coding RNAs}

Long intergenic non-coding RNAs (lincRNAs) are considered the largest and most significant group of lncRNAs, constituting approximately half the overall number of lncRNAs. GENCODE currently lists 7635 lincRNA genes giving rise to 14,379 lincRNA transcripts [4]. They are stand-alone transcripts that are located between protein coding genes and can regulate gene expression by acting either in cis or in trans. Prior to the advent of sequencing, lincRNAs were originally identified using two markers of active transcription: trimethylation of lysine 4 of histone H3 (H3K4me3) and 
trimethylation of lysine 36 of histone H3 (H3K36me3), present at their promoters during RNAPII transcription [6]. LincRNAs appear to have undergone rapid evolution and show variable conservation across species [21]. In a study by Ulitsky et al. mammalian lincRNA orthologues were found for just $5.1 \%$ of zebrafish lincRNA genes, demonstrating poor overall conservation when compared to protein coding genes [26]. Cabili et al. characterised the expression of human lincRNAs across 24 cell types and tissues using RNA-sequencing (RNA-seq). LincRNAs were found to have lower expression levels, fewer exons and to be expressed in a cell-specific manner compared to mRNAs (messenger RNA). LincRNA loci were typically found on average within $40 \mathrm{~kb}$ of protein coding genes [18].

\section{Enhancer RNAs}

Enhancer RNA (eRNA) transcripts are found in both polyadenylated or non-polyadenylated forms and are reported to be bi-directionally expressed at active enhancer regions of the genome [14]. Enhancers are genomic regions located near protein coding genes which contribute to the initiation of transcription by promoting the binding of transcription factors (TFs) and other co-factors. Notably, a study by Kim et al. [40] revealed RNAPII-mediated transcription of eRNAs from enhancer regions in the presence of histone $\mathrm{H} 3$ monomethylated at lysine 4 (H3K4me1) which correlated with the activity of mRNA synthesis. As such, eRNAs are mainly thought to be cis-acting lncRNAs which control promoter and enhancer interactions as well as chromatin structures; resulting in the regulation of gene expression by promoting transcription of neighbouring genes [41,42]. Hence, eRNAs synthesis and enhancer activity are thought to be strongly correlated in regulating the transcriptional activity of neighbouring genes.

\section{Intronic RNAs}

Intronic IncRNAs are entirely transcribed from the introns of annotated protein coding genes in either a sense or antisense direction. These lncRNAs have been associated with the nesting of small ncRNAs such as microRNAs (miRNAs) and small nucleolar RNAs (snoRNAs) as well as circular non-coding RNAs (circRNAs) [43]. In a study by Ayupe et al. intronic RNAs showed evidence of RNAPII-mediated transcription and 5'-cap modifications [44]. The functions of intronic lncRNAs remain largely unclear as they are a relatively unexplored class of lncRNAs and further investigation into their mechanisms of regulation is necessary. However, it has been suggested that intronic lncRNAs are often co-transcribed with their host protein coding gene, thus possibly sharing strong regulatory features and relationships with their host gene [45].

\section{3. circRNAs}

circRNAs are a class of recently discovered regulatory RNAs which were found to interact and regulate the activity of miRNAs, hence usually referred to as "miRNA sponges" [46,47]. A study by Memczak et al. identified approximately 2000 human, 1900 mouse and 700 nematode circRNAs that may be expressed from both coding and non-coding genomic loci [15]. circRNAs have been found to localise primarily in the cytoplasm and inhibit miRNAs by acting as miRNA-competing transcripts [48,49]. Interestingly, another type of circRNAs, known as circular intronic RNAs (ciRNAs) were shown to be located in the nucleus, acting as cis-regulators of RNAPII-mediated transcription and expression of parent genes [43].

\section{Pseudogenes}

The non-coding genome also gives rise to pseudogenes which are derived from protein coding genes that lose their coding potential through evolution [50]. There are currently 14,729 pseudogenes annotated in GENCODE (version 29). However, it appears that a number of pseudogenes may potentially regulate the expression of protein coding genes by processing into short interfering RNAs or acting as miRNA decoys (sponges) to regulate oncogenes during cancer progression [51]. Pseudogenes were also reported to be co-transcribed with their parent gene, functioning as antisense transcripts or even producing short peptides [52]. 


\section{LncRNAs and the Regulation of Biological Function}

LncRNAs are a relatively recently identified class of RNA molecules, and hence their functions and mechanism of action remain largely unexplored. They were originally considered transcriptional noise and although the majority are still likely to be biologically inactive, there is emerging evidence that a substantial number have functional activity. In particular, a number of highly expressed lncRNAs such as HOTAIR (HOX transcript antisense RNA) [53], XIST [31,54], MALAT1 [30], and H19 [55] have been studied in more depth and are relatively well-characterised. Nuclear located lncRNAs are generally associated with chromatin modifications, transcriptional regulation and RNA processing, whereas cytoplasmic lncRNAs have been linked with mRNA stability/translation and as direct agonists/antagonists of protein expression (Figure 2). As such, lncRNA transcripts have been associated with the regulation of all aspects of mRNA processing and protein activity [56].

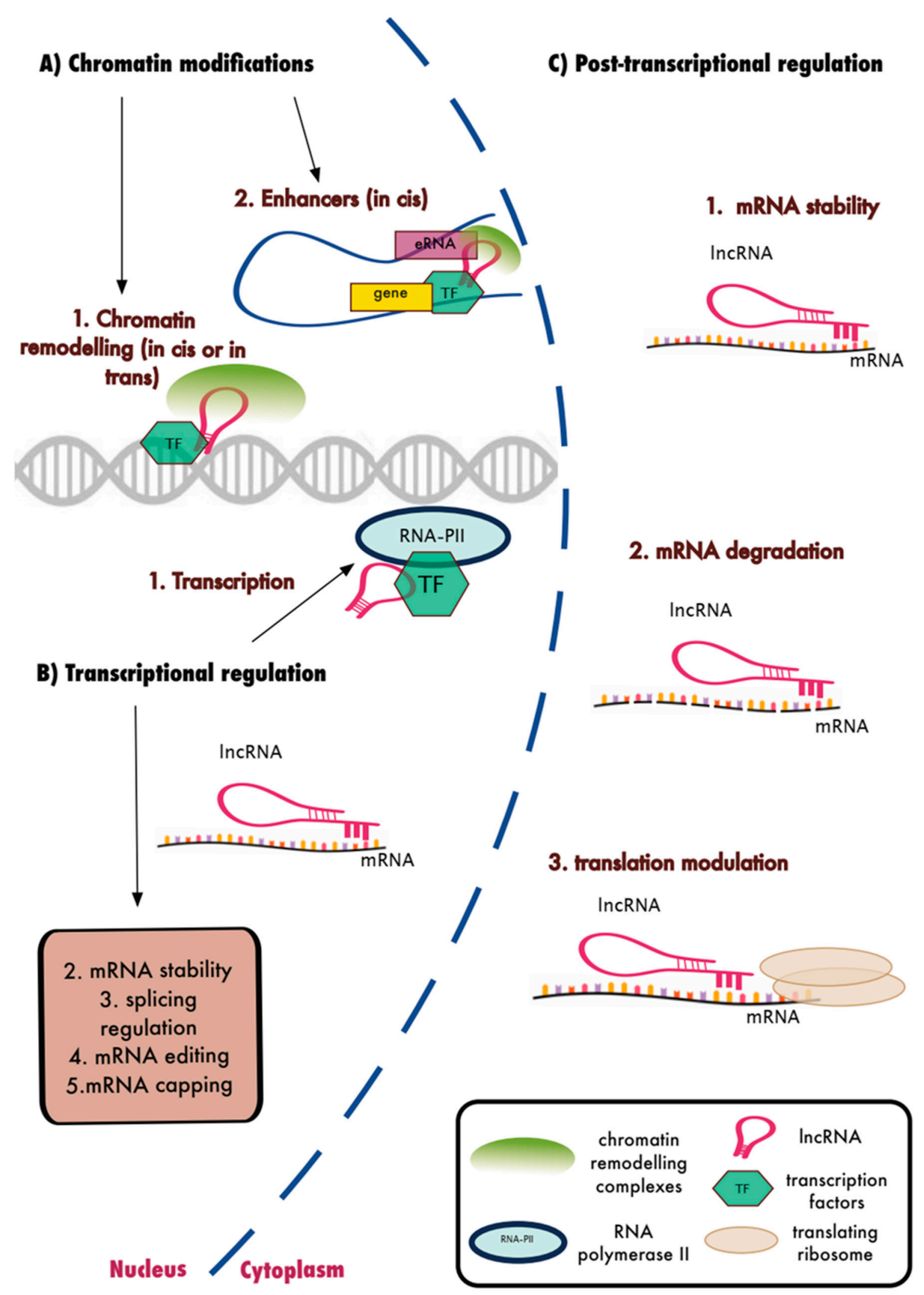

Figure 2. Biological functions of lncRNAs. LncRNAs were shown to interact with protein coding genes and their transcripts to regulate gene expression. (A) Nuclear lncRNAs interact with chromatin remodelling factors and TFs to regulate the expression of neighbouring or distal genes. (B) Nuclear lncRNAs also regulate transcription and several other transcriptional events of RNA processing. (C) Cytoplasmic lncRNAs were shown to interfere with post-transcriptional regulation such as mRNA stability and degradation as well as translational regulation of mRNAs. 
When attempting to examine the role of a lncRNA in a biological response such as innate immunity, it is common to begin by examining their profile of lncRNA expression using techniques such as high throughput RNA sequencing and microarrays. Given the large numbers of lncRNAs identified, experimenters will then often focus upon those that are differentially or selectively expressed, and which are present at high levels. Subsequent functional studies are often undertaken using various RNA silencing techniques both in vitro and in vivo, and in case of the innate immune response have included antisense locked nucleic acid (LNA) [57-60], small interfering RNAs (siRNAs) [61-63] and the CRISPR/Cas9 system [64,65]. Pharmacological inhibitors and gene knockdown approaches can then be employed to examine the intracellular signaling pathways and transcription factors that regulate lncRNA expression. Arguably the biggest challenge is determining their mechanism of action which will commonly begin by investigation of the lncRNA-protein and lncRNA-RNA/DNA interactions using various pull-down techniques such as RNA immunoprecipitation (RIP) [63], capture hybridization analysis of RNA targets (CHART) and chromatin isolation by RNA purification (ChIRP) [66].

\section{LncRNAs and the Innate Immune Response}

The innate immune system is the first line of host defence against infection and involves the recognition and elimination of pathogens. The initial recognition of common pathogenic components including pathogen-associated molecular patterns (PAMPs) and damage-associated molecular patterns (DAMPs) is mediated via pattern recognition receptors (PRRs) such as toll-like receptors (TLRs), the nucleotide binding and oligomerisation domain (NOD) like receptors (NLRs), RIG-I-like receptors (RLRs) and C-type lectin receptors (CLRs). This leads to the subsequent activation of the inflammasome and multiple transcription factors including nuclear factor- $\mathrm{kB}(\mathrm{NF}-\mathrm{\kappa B})$ and the interferon response factors (IRFs), that mediate the inflammatory response involved in the removal of pathogens. These receptors are expressed by the myeloid cells associated with the innate immune system including monocytes, macrophages and dendritic cells, as well as tissue associated cells such as the epithelium and fibroblasts [67]. LncRNA are now implicated in multiple aspects of the innate immune response including the maintenance of hematopoietic stems cells, the differentiation and apoptosis of myeloid cell and the activation of monocytes, macrophages and dendritic cells. An overview of the function and mechanism of action of ncRNAs in the innate immune response is given in Table 1 and is described in more detail in the following sections.

\section{LncRNAs in Hematopoietic Development, Differentiation and Apoptosis}

The maturation of hematopoietic stem cells (HSCs) is a critical step in the development of other blood cells which are grouped into either the lymphoid or the myeloid lineage. Cells of the lymphoid lineage include B and T cells as well as natural killer (NK) cells, while myeloid cells include granulocytes, monocytes, macrophages and megakaryocytes [68].

A study by Venkatraman et al. has shown that the lncRNA H19 plays a crucial role in maintaining adult haematopoietic stem cell quiescence [69]. The maternally specific upstream region of H19, named H19-DMR, activates the Igf2-Igfr1 pathway by the translocation of the phosphorylated FoxO3 (Forkhead box O3) to the cytoplasm when inactivated. This leads to enhanced Igf2 expression and Igfr1 translation which play a significant role in the elevated activation and proliferation of HSCs.

A different study, identified 159 novel lncRNAs enriched in purified mouse HSCs (LncHSCs) using deep sequencing technology [70]. Further analysis of the nucleus-enriched IncRNAs LncHSC-1 and LncHSC-2, demonstrated differential expression between wild-type and Dnmt3a (DNA Methyltransferase 3 Alpha) knock-out HSCs. Significantly, LncHSC-1 was found to be involved in myeloid differentiation while $\mathrm{LncHSC}-2$ demonstrated a role in T cell differentiation and HSC restoration.

The lncRNA Morrbid (myeloid RNA regulator of Bim-induced death) was found to regulate the lifespan of short-lived cells such as monocytes, as well as neutrophils and eosinophils, which make up the majority of human white blood cells. Evidence shows that Morrbid controls the survival of these cells by regulating the transcription of $B c l 2 l 11$, a proapoptotic neighboring gene also known as 
Bim, through the enrichment of the Polycomb Repressive Complex PRC2 at its promoter to promote trimethylation of histone $\mathrm{H} 3$ at lysine 27 (H3K27me3) modifications [64].

\section{LncRNAs in Monocytes and Macrophage Activation}

Pathogen mediated activation of myeloid cells such as monocytes, macrophages and dendritic leads to the rapid release of inflammatory mediators such as cytokine and chemokines, as well as multiple other response that are associated with inflammation including adhesion, chemotaxis, phagocytosis, NADPD oxidase activation, antigen presentation and monocyte to macrophage differentiation [71]. To date, the majority of mechanistic and functional studies have examined the production of inflammatory mediator in response to lipopolysaccharide (LPS), a component of the wall of gram-ve bacteria, which acts predominantly via the TLR4 receptor. These studies have identified a large number of functional lncRNAs, in both humans and mice, and to aid in this description these will be divided to antisense and lincRNAs.

\section{Antisense lncRNAs in Monocytes and Macrophage Activation}

Cyclooxygenase-2 (COX-2), also known as prostaglandin-endoperoxide synthase (PTGS), is an inducible enzyme that is involved in the formation of inflammatory prostanoids. The importance of the enzyme is demonstrated by the fact that pharmaceutical inhibition of COX-2 attenuates both inflammation and pain in patients. Interestingly, a number of lncRNAs have been shown to regulate COX-2 expression including lincRNA-COX2 (see lincRNA section) and the p50-associated COX-2 extragenic RNA (PACER) [61]. PACER is located upstream and is transcribed in the antisense direction through the COX-2 (Cyclooxygenase-2) promoter in response to LPS and PMA (phorbol 12-myristate 13-acetate). It was shown to induce the expression of the COX-2 gene in human U937 monocytic cells by interacting directly with the inhibitory NF- $\mathrm{kB}$ (nuclear factor- $\mathrm{kB}$ ) p50 homodimer. Thus, by occluding the repressive NF- $\mathrm{KB}$ p50 complex in human monocytes and differentiated macrophages, this enables the binding of the active p65/RelA NF- $\mathrm{kB}$ complex and the subsequent recruitment of histone acetyltransferase (HAT) p300, that leads to increased histone acetylation and assembly of RNA-PII pre-initiation complexes [61].

A number of other antisense lncRNAs have also been shown to be induced in response to LPS, including lnc-IL7R (interleukin-7 receptor $\alpha$-subunit) in human THP-1 monocytes [72], NRIR (Negative Regulator of the IFN Response) in human monocytes from systemic sclerosis patients [73], Ptprj-as1 [74] and Mirt2 [75] in mouse macrophages, as well as IL7-AS (antisense to the IL7 gene promoter) in both human THP-1 monocytes and mouse RAW 264.7 macrophages [59]. In addition to LPS, AS-IL1 $\alpha$ was shown to be induced upon infection with Listeria monocytogenes in the spleens of C57BL/6 mice and in isolated BMDMs. In contrast, expression of the sense transcript lnc-13 (which overlaps with Il18rap) was reduced following LPS exposure in primary human and mouse macrophages [76]. Despite being antisense transcripts, knockdown studies have showed that lnc-IL7R [72], NRIR [73], Mirt2 [75] and IL7-AS [59] regulate the expression of multiple inflammatory mediators by acting in trans. Mirt2 was also found to regulate macrophage polarization [75]. The similar pattern of expression levels of the Ptprj gene and its Ptprj-as1 antisense indicates that this lncRNA co-regulates its associated gene by acting in cis [74]. Examination of the pathways regulating their induction indicated that NRIR [73] and IL7-AS [59] expression is mediated via type I IFN (interferon) and NF-KB pathways, respectively. Mechanistic studies have shown that Mirt2 decreases expression of inflammatory cytokines by attenuating Lys63-ubiquitination and oligomerisation of TRAF6 and thereby inhibiting the activation of the NF-KB and MAPK (mitogen-activated protein kinase) pathways. Lnc-13 is thought to regulate gene expression by interacting directly with hnRNPL (heterogenous nuclear ribonucleoprotein L) to mediate the localisation of Hdac1 (Histone deacetylase 1) on chromatin [76]. In contrast, AS-IL1 $\alpha$ which is encoded within the IL- $1 \alpha$ locus, was found to regulate $I L-1 \alpha$ by recruiting RNAP- II to the IL-1 $\alpha$ promoter during transcription induced by LPS [77]. 


\section{LincRNAs in Monocytes and Macrophage Activation}

As with antisense lncRNAs, the naming of lincRNAs is often based upon the nearest protein coding gene. Like PACER, lincRNA-COX2 is located proximal to the COX2 (Ptgs2) gene and was originally shown by Carpenter et al. [78] to regulate the expression of multiple genes in non-stimulated mouse bone marrow derived macrophages (BMDMs). In addition, following exposure to the TLR1/2 agonist Pam3CSK $_{4}$ (palmitoyl-3-cysteinyl-seryl-(lysyl) 4 ), lincRNA-COX2 induction which is mediated via NF- $\mathrm{kB}$, was demonstrated to regulate the downregulation and upregulate of 787 and 713 genes, respectively [78]. Mechanistic studies identified hnRNP-A/B and hnRNP-A2/B1 (heterogeneous nuclear ribonucleoproteins) as potential binding partners of lincRNA-COX2. Subsequent reports have demonstrated that linc-COX2 also regulates the late inflammatory response upon exposure to LPS in murine macrophages [79]. In this paper, lincRNA-COX2 was shown to be integrated into the SWI/SNF (Switch/Sucrose NonFermentable) complex that controls the activity of NF-kB and the chromatin re-modelling associated with the transcription of the late-primary inflammatory genes. Another study by Xue et al. [80] has identified lincRNA-COX2 as a modulator of the inflammasome sensor NLRP3 and ASC adaptor, by binding to NF-kB p65 upon LPS stimulation of BMDMs. LincRNA-COX2 knockdown was found to inhibit caspase- 1 activation, decrease secretion of IL- $1 \beta$ and TRIF (TIR-domain-containing adapter-inducing interferon- $\beta$ ) cleavage; ultimately increasing TRIF-mediated BMDM autophagy. In support of these earlier studies, Elling et al. [81] employed a knockout mouse model to confirm that lincRNA-COX2 regulated the inflammatory gene expression in trans during LPS-induced sepsis. Interestingly, the study revealed that lincRNA-COX2 might act as an eRNA in cis since it was observed that knockout inhibited the expression of neighboring genes across a number of different tissues.

The conserved IncRNA MALAT1 is another lincRNA that has been reported to regulate the innate immune response in multiple publications. A study by Zhao et al. [82] demonstrated that MALAT1 was upregulated in response to LPS activation and knock-down studies showed increased expression of inflammatory cytokines such as TNF- $\alpha$, and IL-6 but had no effect on IL-1 $\beta$. MALAT1 was also shown to inhibit the activity of NF-KB by binding to the nuclear p65/p50 heterodimer; thus regulating the activity of other NF- $\mathrm{KB}$ dependent genes. A more recent study by Cui et al. [83] demonstrated that MALAT1 regulates macrophage activation in response to pulmonary injury. MALAT1 expression was found to be elevated in LPS-activated macrophages and downregulated in IL-4-exposed cells. Interestingly, knock-down of MALAT1 increased IL-4-induced differentiation of M2 macrophages and induced a pro-fibrotic cell phenotype. MALAT1 knock-out mice also demonstrated decreased pulmonary inflammation accompanied with increased lung fibrosis.

Gene profiling has also shown differential expression of multiple other lincRNAs in response to inflammatory mediators such as LPS, including THRIL (TNF- $\alpha$ and hnRNPL related immunoregulatory lincRNA) [84] and IL1ß-RBT46 [85] in human, as well as lincRNA-EPS (erythroid prosurvival or Ttc39aos1) [86], linc-Tnfaip3 (tumor necrosis factor $\alpha$-induced protein 3) [87], NTT (noncoding transcript in T cells) [88] and FIRRE [89] in mice (Table 1). lincRNA-EPS was originally discovered as a regulator of differentiation and apoptosis in erythroid cells [90] whilst NTT (noncoding transcript in T cells) was shown to be elevated in peripheral blood mononuclear cells (PBMCs) from rheumatoid arthritis (RA) patients [88]. Investigation of the mechanisms that drive lincRNA transcription indicated that IL1 $\beta$-RBT46 [85] and FIRRE [89] expression was mediated via NF- $\mathrm{KB}$, whilst NTT is modulated by C/EBP $\beta$ [88].

Knockdown studies have demonstrated that these lincRNAs also regulate the expression of multiple inflammatory genes in trans. In a similar fashion to lincRNA-COX2 and Lnc-13, the actions of many of these lincRNAs has been linked to an interaction with heterogeneous nuclear ribonucleoproteins (hnRNPs). Thus, THRIL [84] and lincRNA-EPS [91] were shown to interact with hnRNPL, whilst in-depth analysis in lincRNA-EPS deficient mice demonstrated this to be linked to elevated levels of H3K4me3, alternating nucleosome positioning and chromatin accessibility at the promoters of immune responsive genes [91]. FIRRE was found to interact with hnRNP-U to regulate the stability of inflammatory-associated genes by targeting the adenylate-uridylate-rich elements 
(AREs) of mRNAs [89]. Similarly, NTT (noncoding transcript in T cells) was demonstrated to bind the promoter regions of the PBOV1 (prostate and breast cancer overexpressed 1) gene via hnRNP-U. Elevated PBOV1 then resulted in expression of the $I L-10$ and CXCL10 mRNA levels, macrophage differentiation and cell cycle G1 arrest. Of relevance, this C/EBP $\beta / N T T / P B O V 1$ complex is suggested to play a regulatory role in the inflammatory response of monocytes associated with pathogenesis of rheumatoid arthritis [88]. In contrast to an action mediated via hnRNPs, linc-Tnfaip3 was shown to regulate the activity of inflammatory genes by controlling the assembly of the NF- $\mathrm{kB} / \mathrm{Hmgb} 1$ (high-mobility group box 1) complex upon LPS stimulation.

Finally, Covarrubias et al. [65] used the CRISPR/Cas9 gene deletion technology to study lncRNAs that regulate the NF-KB signalling pathway and demonstrated that lincRNA-Cox2 and lincRNA-AK170409 are crucial regulators of inflammation. As such, the nuclear-enriched lincRNA-AK170409 was found to be a novel modulator of several genes associated with inflammation and lincRNA-Cox 2 was shown to mediate IкB $\alpha$ degradation in the cytoplasm of LPS-stimulated immortalized murine bone marrow-derived macrophages (iBMDM).

\section{LncRNAs in Dendritic Cells}

DCs are specialised antigen-presenting cells (APCs) that act as a link between innate and adaptive immunity [92]. Indeed, the first report examining the potential role of lncRNAs in the immune response involved studies of LPS-induced activation of $\mathrm{CD} 11 \mathrm{C}^{+}$mouse bone marrow-derived DCs. This report by Guttman et al. [6] employed chromatin markers such as H3K4me3 and H3K26me3 to demonstrates upregulation of 20 lincRNAs including lincRNA-COX2.

Subsequent studies have found MALAT1 to be upregulated via an NF-KB-dependent, in CD11 $\mathrm{c}^{+}$ DCs from LPS-stimulated mice [93]. Overexpression of MALAT1 caused a more tolerogenic phenotype in LPS-activated DCs and elevated IL-10 production. Evidence suggests that tolerogenic DCs build immune tolerance by regulating $\mathrm{T}$ cell activity and generating immunosuppressive regulatory $\mathrm{T}$ cells (Tregs). Thus, Wu et al. [93] presents lncRNA MALAT1 as a novel modulator of tolerogenic DCs and immune tolerance by regulating the activity of the miRNA-155/DC-SIGN (dendritic cell- specific intercellular adhesion molecule-3 grabbing nonintegrin)/IL10 axis (Figure 3).

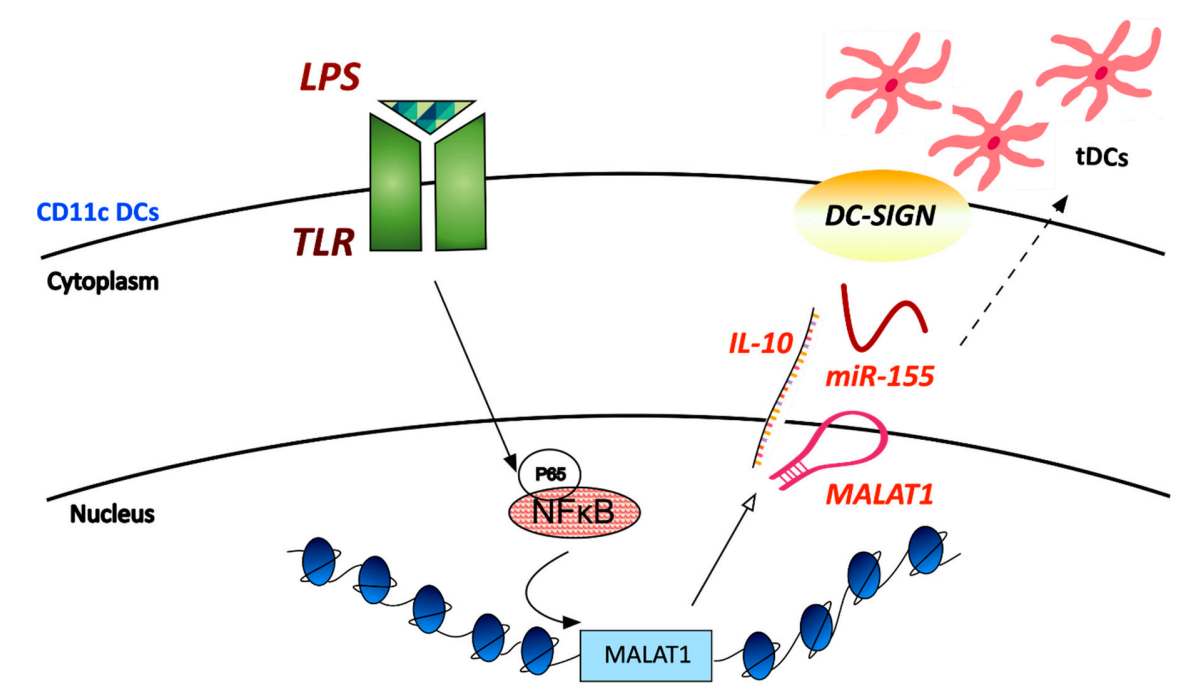

Figure 3. Expression of $M A L A T 1$ is increased in response to inflammatory stimuli in $\mathrm{CD} 11 \mathrm{c}^{+}$cells of tolerized allograft cardiac tissue. LPS-induced transcription of MALAT1 was shown to be dependent on the p65- associated activation of the NF- $\mathrm{B}$ pathway and to increase secretion of the immunosuppressive cytokine IL-10. DC-SIGN (dendritic cell- specific intercellular adhesion molecule-3 grabbing nonintegrin) was also shown to be controlled by MALAT1 and to act as a miR-155 sponge to maintain the tolerogenic ability of the tDCs (tolerogenic DCs). 
The $\operatorname{lnc}-D C$ was also shown to be expressed in human conventional DCs and to regulate cell differentiation by interacting directly with STAT3 (signal transducer and activator of transcription 3). More specifically, knockdown studies have shown that $\operatorname{lnc}-D C$ prevented differentiation of BMDMs in vivo and human monocytes in vitro. $L n c-D C$ was found to directly bind to STA3 in the cytoplasm to promote phosphorylation of STAT3 on Y705 (tyrosine-705), and to prevent interaction and dephosphorylation by the tyrosine-specific protein phosphatase SHP1 [94].

\section{LncRNAs in Fibroblasts}

Although fibroblasts are not considered to be in the group of immune cells, they have a crucial role in wound healing and are important in providing a physical barrier as a line of defence to pathogens. Fibroblasts produce inflammatory mediators in response to trauma or infection and they may express TLRs, synthesise antimicrobial peptides and trigger the innate immune response [95].

The lncRNA Lethe, transcribed from the Rps15a pseudogene, was the first lncRNA found to play a role in inflammation in mouse embryonic fibroblasts. The study by Rapicavoli et al. [96] characterised Lethe as a $697 \mathrm{bp}$ long unspliced RNA located on chromosome 4 which is directly regulated by TNF- $\alpha$, IL-1 $\beta$ and dexamethasone. RNA-seq analysis identified several lncRNAs that were differentially expressed upon TNF- $\alpha$ stimulation including 54 pseudogenes, of which a significant number were shown to be regulated by NF-KB. More specifically, further work focused on the role of Lethe in inflammation revealed that it is expressed in response to both TNF- $\alpha$ and IL-1 $\beta$ cytokines and it is primarily associated with chromatin. Interestingly, Lethe was shown to inhibit NF- $\kappa B$ DNA binding activity by directly interacting with the NF- $\mathrm{kB}$ subunit RelA, acting as a negative regulator of the inflammatory response (Figure 4). A more recent study by Zgheib et al. [97] investigated the role of Lethe in mouse macrophages to show that Lethe regulates ROS (reactive oxygen species) production in a model of diabetic wound healing by modulating NF- $\mathrm{kB}$ signalling and the expression of the NOX2 (NADPH oxidase 2) gene.

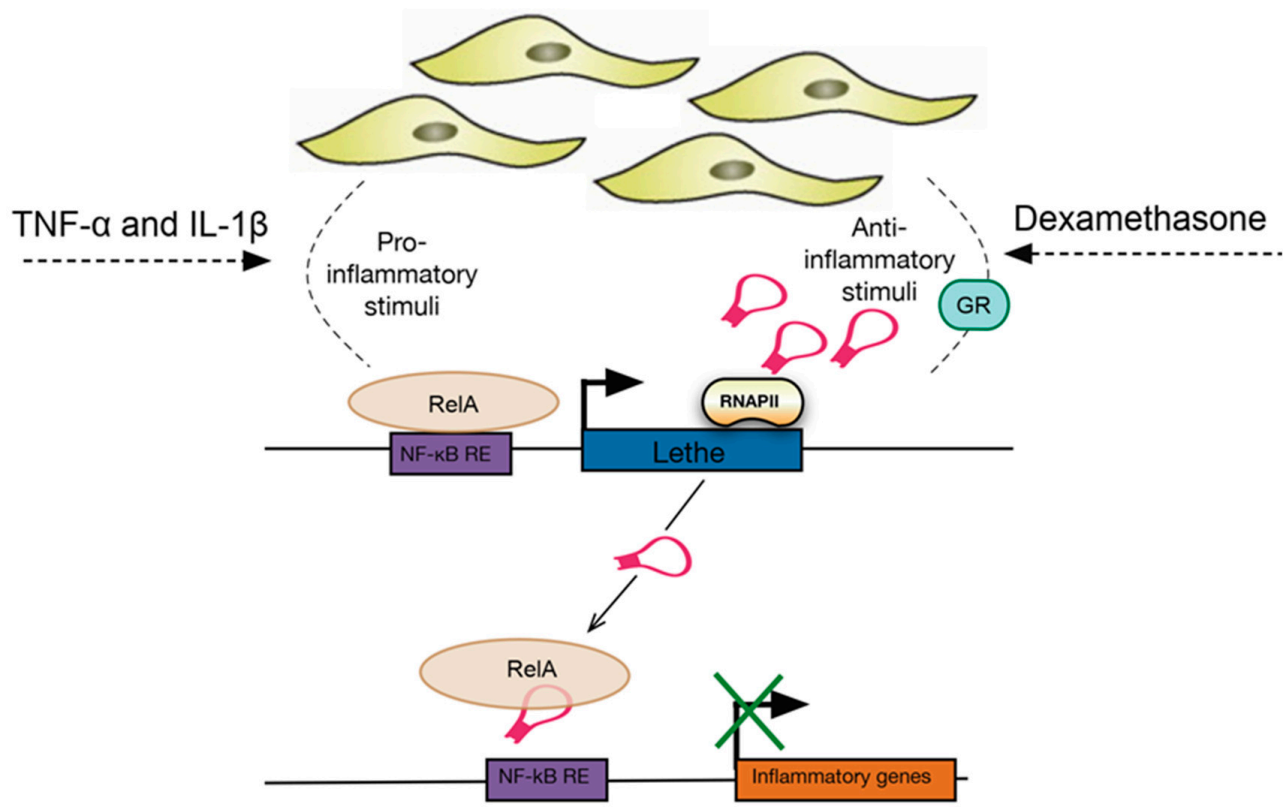

Figure 4. Lethe regulates gene expression upon exposure to TNF- $\alpha, \mathrm{IL}-1 \beta$ and dexamethasone in fibroblasts. Activation of Lethe by either pro- or anti-inflammatory stimuli was found to inhibit expression of inflammatory genes by binding directly to RelA and preventing NF- $\mathrm{BB}$ binding to DNA. Therefore, Lethe is suggested to act as a negative regulator of NF- $\mathrm{KB}$ and the activation of the inflammatory response. GR, glucocorticoid receptor; NF-kB RE, NF- $\mathrm{BB}$ response element; RelA, transcription factor p65. 
Interestingly, IL7AS and MIR3142HG were also found to be implicated in the inflammatory response of primary human lung fibroblasts in response to IL-1 $\beta$ activation [60]. RNA-seq analysis identified 14 lncRNAs to be differentially expressed upon stimulation, including IL7AS and MIR3142HG which demonstrated the most significant upregulation. Knockdown studies showed the IL7AS was a negative regulator of IL-6 release, while MIR3142HG was a positive regulator of CCL2 and IL-8 protein release and both lncRNAs were found to be regulated by the NF- $\mathrm{kB}$ pathway.

\section{LncRNAs in Epithelial Cells}

Similar to fibroblasts, epithelial cells are not considered to be primarily immune cells; however, they play a crucial role in the initiation, regulation and maintenance of the innate immune response. Moreover, epithelial cells may trigger the adaptive immune response as well as inhibit potential excessive immune stimuli to prevent damage to the epithelium [98].

IL-1 $\beta$ was shown to drive the expression of lncRNAs in human epithelial cells. More specifically, 34 lncRNAs were differentially expressed in response to IL-1 $\beta$ activation including IL7AS which was amongst the most significantly upregulated lncRNAs. IL7AS was found to mediate the inflammatory activity of the A549 cell line by regulating the expression of IL- 6 mRNA and protein release upon knockdown studies [59].

LincRNA-COX2 was found to also modulate inflammation in murine intestinal epithelial cells [99]. LincRNA-COX2 was shown to be one of the most significantly upregulated genes in response to TNF- $\alpha$ stimulation and its induced transcription was dependent upon the activation of the NF- $\mathrm{kB}$ signalling pathway. Silencing of $\operatorname{lin} c R N A-C O X 2$ increased the expression of the $I l 12 b$ gene by recruiting the $\mathrm{Mi}-2 / \mathrm{NuRD}$ (Mi-2/nucleosome remodelling and deacetylase) repressor complex to its promoter region as well as by promoting histone modifications at the Il12b promoter upon TNF- $\alpha$ activation. 
Table 1. LncRNAs associated with the innate immune response.

\begin{tabular}{|c|c|c|c|c|c|}
\hline LncRNA Name & Stimuli & Cell Type & Function & Mechanism & Refs \\
\hline H19 & N/A & $\begin{array}{l}\text { Mouse hematopoietic stem } \\
\text { cells }\end{array}$ & Maintains HSC quiescence & $\begin{array}{l}\text { Regulates the Igf2-Igfr1 pathway via the } \\
\text { translocation of FOX3 to the cytoplasm }\end{array}$ & [69] \\
\hline LncHSC-1/2 & N/A & $\begin{array}{l}\text { Mouse hematopoietic stem } \\
\text { cells }\end{array}$ & $\begin{array}{l}\text { LncHSC-1 regulates myeloid } \\
\text { differentiation and LncHSC-2 } \\
\text { cell self-renewal and } \\
\text { differentiation }\end{array}$ & $\begin{array}{l}\text { LncHSC-2 recruits the hematopoietic TF E2A } \\
\text { to its binding sites }\end{array}$ & [70] \\
\hline PACER & PMA and LPS & Human monocytes (U937) & Promotes COX2 expression & $\begin{array}{l}\text { Binds to the repressive p50 NF- } \mathrm{kB} \text { subunit of } \\
\text { COX2 promoter to enable p300 HAT } \\
\text { recruitment in order to increase histone } \\
\text { acetylation and initiate the assembly of } \\
\text { RNAP-II complexes }\end{array}$ & [61] \\
\hline Morrbid & N/A & $\begin{array}{l}\text { Human and mouse } \\
\text { monocytes, neutrophils, } \\
\text { eosinophils }\end{array}$ & $\begin{array}{l}\text { Controls the lifespan of } \\
\text { monocytes, neutrophils and } \\
\text { eosinophils }\end{array}$ & $\begin{array}{l}\text { Regulates Bcl2111 (Bim) transcription by } \\
\text { promoting PCR2 enrichment at its promoter } \\
\text { and deposition of H3K27me3 }\end{array}$ & [64] \\
\hline THRIL & ${\mathrm{PMA} \mathrm{Pam} 3 \mathrm{CSK}_{4}}_{4}$ & Human monocytes (THP-1) & $\begin{array}{c}\text { Regulates the expression of the } \\
\text { innate-associated mediators } \\
\text { TNF- } \alpha, \text { CCL1, IL-8, CSF1 and } \\
\text { CXC10 }\end{array}$ & $\begin{array}{l}\text { Forms a functional lncRNA-hnRNPL } \\
\text { complex in order to regulate TNF- } \alpha \\
\text { transcription by binding to its promoter }\end{array}$ & [84] \\
\hline \multirow{5}{*}{ LincRNA-COX2 } & $\mathrm{Pam}_{3} \mathrm{CSK}_{4}$ & $\begin{array}{l}\text { Mouse bone marrow derived } \\
\text { macrophages }\end{array}$ & $\begin{array}{l}\text { Regulates the expression of } \\
\text { several immune genes }\end{array}$ & $\begin{array}{l}\text { Interacts with the nuclear proteins } \\
\text { hnRNP-A/B and hnRNP-A2/B1 }\end{array}$ & \multirow{5}{*}[6,78-81,99]{} \\
\hline & Multiple & $\begin{array}{l}\text { LincRNA-Cox } 2 \text { deficient mice } \\
\text { and macrophages }\end{array}$ & $\begin{array}{l}\text { Regulates the expression of } \\
\text { several immune genes }\end{array}$ & $\begin{array}{l}\text { Functions as an eRNA to regulate the } \\
\text { activity of the COX2 gene but also } \\
\text { demonstrates in trans-regulation of } \\
\text { immune-associated genes in vivo }\end{array}$ & \\
\hline & LPS & $\begin{array}{l}\text { Mouse macrophages (RAW } \\
264.7 \text { and primary peritoneal) }\end{array}$ & $\begin{array}{l}\text { Regulates the expression of } \\
\text { NF-kB-regulated inflammatory } \\
\text { genes }\end{array}$ & $\begin{array}{l}\text { Interacts with the SWI/SNF complex to } \\
\text { regulate the assembly of NF- } \mathrm{KB} \text { subunits and } \\
\text { chromatin remodelling }\end{array}$ & \\
\hline & TLR4 ligand & $\begin{array}{l}\text { Mouse bone-marrow-derived } \\
\text { dendritic cells }\end{array}$ & N/A & Demonstrates NF- $\mathrm{kB}$-dependent expression & \\
\hline & TNF- $\alpha$ & $\begin{array}{l}\text { Murine intestinal epithelial } \\
\text { cells (IEC4.1 cell line) }\end{array}$ & $\begin{array}{l}\text { Regulates the expression of the } \\
\text { Ill2b gene }\end{array}$ & $\begin{array}{l}\text { Demonstrates NF-kB-dependent expression } \\
\text { and promotes the recruitment of the } \\
\text { Mi-2/NuRD complex to the } I l 12 b \text { promoter }\end{array}$ & \\
\hline
\end{tabular}


Table 1. Cont.

\begin{tabular}{|c|c|c|c|c|c|}
\hline LncRNA Name & Stimuli & Cell Type & Function & Mechanism & Refs \\
\hline AS-IL1 $\alpha$ & $\begin{array}{l}\text { TLR ligands and } \\
\text { Listeria } \\
\text { monocytogenes }\end{array}$ & $\begin{array}{l}\text { Mouse bone marrow derived } \\
\text { macrophages }\end{array}$ & Regulates IL- $1 \alpha$ transcription & $\begin{array}{c}\text { Facilitates RNAP-II recruitment to the IL- } 1 \alpha \\
\text { locus and demonstrates NF-kB-dependent } \\
\text { expression }\end{array}$ & [77] \\
\hline $\begin{array}{l}\text { IL1 } \beta \text {-eRNA } \\
\text { IL1 } \beta \text {-RBT46 }\end{array}$ & Dinc & $\begin{array}{l}\text { Human monocytes (THP-1 and } \\
\text { primary) }\end{array}$ & $\begin{array}{l}\text { Regulate the expression of } \\
\text { IL-1 } \beta \text { and CXCL8 } \\
\end{array}$ & Demonstrate NF- $к B$-dependent expression & [85] \\
\hline Lnc-IL7R & LPS & Human monocytes (THP-1) & $\begin{array}{l}\text { Regulates the expression of the } \\
\text { inflammatory mediators IL-6, } \\
\text { IL-8, E-selectin and VCAM-1 }\end{array}$ & $\begin{array}{l}\text { Regulates deposition of H3K27me3 at the } \\
\text { promoters of the E-selectin and VCAM-1 } \\
\text { genes }\end{array}$ & [72] \\
\hline Ptprj-as1 & $\begin{array}{c}\text { LPS } \\
\text { Pam3Cys }\end{array}$ & $\begin{array}{l}\text { Mouse bone marrow derived } \\
\text { macrophages and RAW } 264.7\end{array}$ & N/A & N/A & [74] \\
\hline \multirow[t]{2}{*}{ IL7AS } & LPS & $\begin{array}{c}\text { Human monocytes (THP-1), mouse } \\
\text { macrophages } \\
\text { (RAW 264.7) }\end{array}$ & \multirow[t]{2}{*}{$\begin{array}{l}\text { Regulates IL-6 expression and } \\
\text { release }\end{array}$} & \multirow[t]{2}{*}{ Demonstrates NF-kB-dependent expression } & \multirow[t]{2}{*}[59,60]{} \\
\hline & IL-1 $\beta$ & $\begin{array}{l}\text { Human epithelial cells (A549 cell line) } \\
\text { Human lung fibroblasts (primary) }\end{array}$ & & & \\
\hline Linc-EPS & Multiple & $\begin{array}{c}\text { Mouse bone marrow derived } \\
\text { macrophages }\end{array}$ & $\begin{array}{l}\text { Represses the inflammatory } \\
\text { response by inhibiting IRGs } \\
\text { expression }\end{array}$ & $\begin{array}{l}\text { Interacts with hnRNPL via a CANACA } \\
\text { motif in its } 3^{\prime} \text { region and regulates } \\
\text { nucleosome positioning at IRG promoters }\end{array}$ & [86] \\
\hline LincRNA-Tnfaip3 & LPS & $\begin{array}{c}\text { Mouse macrophages (RAW } 264.7 \text { and } \\
\text { primary mouse peritoneal } \\
\text { macrophages) }\end{array}$ & $\begin{array}{l}\text { Regulates the expression of } \\
\text { several NF- } \mathrm{kB} \text { mediated } \\
\text { inflammatory genes }\end{array}$ & $\begin{array}{l}\text { Directly interacts with Hmgb1 and NF- } \mathrm{B} \text { to } \\
\text { form a functional complex to regulate } \\
\text { Hmgb1-mediated histone modifications }\end{array}$ & [87] \\
\hline Lnc-13 & LPS & $\begin{array}{l}\text { Human monocytes (primary and } \\
\text { U937, THP-1) and mouse bone } \\
\text { marrow derived macrophages }\end{array}$ & $\begin{array}{l}\text { Suppresses the expression of } \\
\text { several immune-associated } \\
\text { genes }\end{array}$ & $\begin{array}{l}\text { Demonstrates NF-kB-dependent expression } \\
\text { and interacts with Hdac1 on chromatin and } \\
\text { hnRNPD to regulate gene expression }\end{array}$ & [76] \\
\hline NRIR & LPS & Human monocytes (primary) & $\begin{array}{l}\text { Regulates the expression of } \\
\text { several interferon-stimulated } \\
\text { genes and protein release of } \\
\text { CXCL10 and CCL8 }\end{array}$ & $\begin{array}{l}\text { Demonstrates type I IFN-dependent } \\
\text { expression }\end{array}$ & [73] \\
\hline NTT & N/A & $\begin{array}{l}\text { Peripheral blood mononuclear cells } \\
\text { (PBMCs) } \\
\text { Human monocytes (THP-1) }\end{array}$ & $\begin{array}{l}\text { Regulates cell cycle G1 arrest } \\
\text { and differentiation as well as } \\
\text { expression of IL-10 and CXCL10 }\end{array}$ & $\begin{array}{c}\text { Interacts with the TF C/EBP } \beta \text { and the } \\
\text { promoter of its neighbouring gene PBOV1 } \\
\text { via hnRNP-U }\end{array}$ & [88] \\
\hline Mirt2 & LPS & $\begin{array}{l}\text { Peritoneal macrophages (C57BL/6 } \\
\text { mice) } \\
\text { HEK293T and RAW264.7 cells }\end{array}$ & $\begin{array}{l}\text { Regulates macrophage } \\
\text { polarisation and aberrant } \\
\text { inflammatory activity }\end{array}$ & $\begin{array}{l}\text { Inhibits TRAF6 Lys63-mediated } \\
\text { ubiquitination and the activation of the } \\
\text { MAPK and NF-kB pathways }\end{array}$ & [75] \\
\hline
\end{tabular}


Table 1. Cont.

\begin{tabular}{|c|c|c|c|c|c|}
\hline Lnc-Lsm3b & $\begin{array}{l}\text { Viral RNA } \\
\text { molecules }\end{array}$ & $\begin{array}{l}\text { Mouse macrophages (peritoneal, } \\
\text { RAW 264.7), L929 and HEK293T } \\
\text { cell lines }\end{array}$ & $\begin{array}{l}\text { Inactivates late RIG-1 innate } \\
\text { activity and type I IFNs production }\end{array}$ & $\begin{array}{c}\text { Acts as a decoy by saturating RIG-1 binding } \\
\text { sites to inhibit inflammation and to prevent } \\
\text { tissue host damage }\end{array}$ & [63] \\
\hline \multirow[t]{3}{*}{ MALAT1 } & PMA, LPS & $\begin{array}{l}\text { Human monocytes (THP-1), } \\
\text { mouse macrophages (RAW 264.7) }\end{array}$ & $\begin{array}{l}\text { Regulates the expression of } \\
\text { inflammatory genes such as IL- } 6 \\
\text { and TNF- } \alpha\end{array}$ & $\begin{array}{l}\text { Interacts with NF- } \mathrm{kB} \text { p50/p65 subunits to } \\
\text { inhibit NF- } \mathrm{kB} \text { DNA binding activity }\end{array}$ & \multirow[t]{3}{*}[82,83,93]{} \\
\hline & PMA, LPS, IL-4 & $\begin{array}{c}\text { Mouse macrophages (BMDM), } \\
\text { human monocytes (PBMCs, } \\
\text { THP-1) }\end{array}$ & $\begin{array}{l}\text { Regulates LPS-mediated M1 } \\
\text { macrophage activation and } \\
\text { IL-4-mediated M2 differentiation } \\
\text { and pro-fibrotic phenotype }\end{array}$ & $\begin{array}{c}\text { Demonstrates Clec16a-dependent expression } \\
\text { and regulation of mitochondrial pyruvate } \\
\text { carriers }\end{array}$ & \\
\hline & LPS & $\begin{array}{l}\text { Mouse bone-marrow-derived } \\
\text { dendritic cells }\end{array}$ & $\begin{array}{l}\text { Induces increased tolerogenic } \\
\text { activity of DCs }\end{array}$ & $\begin{array}{l}\text { Enhances DC-SIGN expression, IL-10 } \\
\text { production and acts as an miR-155 sponge }\end{array}$ & \\
\hline FIRRE & LPS & $\begin{array}{c}\text { Human macrophages (U937) } \\
\text { Human intestinal epithelial cells } \\
\text { (SW480) } \\
\text { Mouse macrophages (RAW264.7) }\end{array}$ & $\begin{array}{l}\text { Regulates expression of several } \\
\text { inflammatory genes }\end{array}$ & $\begin{array}{c}\text { Demonstrates NF-kB-dependent expression } \\
\text { and } \\
\text { interacts with hnRNPU to regulate mRNA } \\
\text { stability by targeting their AREs }\end{array}$ & [89] \\
\hline $\begin{array}{l}\text { LincRNA-AK1704( } \\
\text { LincRNA-Cox2 }\end{array}$ & TLR ligands & $\begin{array}{l}\text { Immortalized murine bone } \\
\text { marrow-derived macrophages } \\
\text { (iBMDM) }\end{array}$ & $\begin{array}{l}\text { Both regulate NF-kB-dependent } \\
\text { signalling }\end{array}$ & $\begin{array}{c}\text { Both IncRNAs demonstrate } \\
\text { NF- } k B-\text { dependent activity - } \\
\text { LincRNA-COX2 promotes I } \mathrm{B} \alpha \text { degradation }\end{array}$ & [65] \\
\hline Lnc-DC & N/A & $\begin{array}{l}\text { Human conventional dendritic } \\
\text { cells }\end{array}$ & Regulates DC differentiation & $\begin{array}{l}\text { Binds directly to STAT3 to prevent } \\
\text { dephosphorylation of Y705 by SHP1 }\end{array}$ & [94] \\
\hline \multirow[t]{2}{*}{ Lethe } & $\begin{array}{l}\text { TNF- } \alpha, \text { IL- } 1 \beta, \\
\text { dexamethasone }\end{array}$ & $\begin{array}{l}\text { MEF lines (mouse embryonic } \\
\text { fibroblasts) }\end{array}$ & $\begin{array}{l}\text { Regulates the expression of several } \\
\text { NF- } \mathrm{B} B \text { mediated inflammatory } \\
\text { genes }\end{array}$ & $\begin{array}{c}\text { Interacts with the RelA (p65) subunit of } \\
\text { NF- } k B \text { to inhibit DNA binding and gene } \\
\text { activation }\end{array}$ & \multirow[t]{2}{*}[96,97]{} \\
\hline & Glucose & $\begin{array}{l}\text { Mouse macrophages (RAW } 264.7 \\
\text { and bone marrow derived } \\
\text { macrophages) }\end{array}$ & $\begin{array}{l}\text { Regulates ROS production and } \\
\text { NOX2 gene expression }\end{array}$ & $\begin{array}{l}\text { Interacts with the NF- } \mathrm{kB} \text { p } 65 \text { subunit to } \\
\text { control its translocation to the nucleus }\end{array}$ & \\
\hline MIR3142HG & IL-1 $\beta$ & Human lung fibroblasts (primary) & $\begin{array}{l}\text { Regulates CCL2 and IL-8 mRNA } \\
\text { and protein release }\end{array}$ & Demonstrates NF-kB-dependent expression & [60] \\
\hline \multirow[t]{2}{*}{ NEAT1 } & $\begin{array}{l}\text { Influenza, HSV-1, } \\
\text { poly I:C }\end{array}$ & $\begin{array}{l}\text { Human epithelial cells (A549 cell } \\
\text { line) and HeLa cells }\end{array}$ & Regulates expression of IL-8 & $\begin{array}{l}\text { Interacts and relocates SFPQ from the IL8 } \\
\text { promoter to the paraspeckles }\end{array}$ & \multirow[t]{2}{*}[100,101]{} \\
\hline & Multiple & $\begin{array}{l}\text { HUVEC cells (Human umbilical } \\
\text { vein endothelial cells), HEK293 } \\
\text { cells, HeLa and } 293 \text { T cells }\end{array}$ & $\begin{array}{l}\text { Regulates the DNA-mediated } \\
\text { innate immune response }\end{array}$ & $\begin{array}{l}\text { Interacts with HEXIM1 to form the } \\
\text { HDP-RNP complex which is required for the } \\
\text { cGAS-STING-IRF3 pathway }\end{array}$ & \\
\hline LncITPRIP-1 & Viral infections & $\begin{array}{l}\text { Huh7, Huh7.5, Huh7.5.1-MAVS, } \\
\text { FL-neo, and HEK293T cells }\end{array}$ & $\begin{array}{l}\text { Promotes the activation of the } \\
\text { innate immune response }\end{array}$ & $\begin{array}{l}\text { Binds to the C-terminus of MDA5 and } \\
\text { promotes its oligomerisation to enhance IFN } \\
\text { signalling and production }\end{array}$ & [103] \\
\hline $\begin{array}{l}\text { NEAT1v2 } \\
\text { eRNA07573 }\end{array}$ & $\begin{array}{l}\text { Salmonella } \\
\text { infection }\end{array}$ & HeLa cells & $\begin{array}{l}\text { Regulate expression of } \\
\text { immune-associated genes and } \\
\text { response to antibacterial defence }\end{array}$ & $\begin{array}{l}\text { Inhibit levels of the exosome/NEXT } \\
\text { components and demonstrate elevated } \\
\text { transcript stability }\end{array}$ & [102] \\
\hline
\end{tabular}




\section{LncRNAs and Viral Infections}

The nuclear located 4-kb lncRNA NEAT1 (nuclear paraspeckle assembly transcript 1) was originally shown to be essential for the structure and formation of paraspeckles [29]. However, its expression and the increased formation of paraspeckles has also been associated with viral infections such as influenza and herpes simplex virus-1 (HSV-1), as well activation following exposure to the immunostimulant polyinosinic:polycytidylic acid (poly I:C). NEAT1 was demonstrated to induce the expression of genes associated with viral infections such as IL8. Significantly, the NEAT1 binding splicing factor proline/glutamine-rich (SFPQ) appeared to repress IL8 expression; thus, NEAT1 was found to relocate SFPQ to the paraspeckles in order to remove SFPQ from the IL-8 promoter and initiate transcription of IL8 [100]. A different study by Morchikh et al. [101], identified a ribonuclear complex named HDP-RNP around the IncRNA NEAT1 and HEXIM1 to control the DNA-mediated innate immune response by regulating the cGAS (cyclic GMP-AMP synthase)-STING (stimulator of interferon genes) pathway. Imamura et al. [102] has also demonstrated that NEAT has a role in bacterial infection following studies of the nuclear lncRNAs Salmonella infected HeLa cells. Interestingly, inhibition of the lncRNAs NEAT1v2 and $e R N A 07573$ resulted in elevated susceptibility to the bacterium and altered-regulation of genes associated with the innate immune response. In contrast to uninfected cells, Salmonella-exposed cells showed decreased levels of the nuclear exosome targeting (NEXT) complex, RRP6 (EXOSC10) and the RNA helicase MTR4, leading to the stabilisation of unstable RNAs; suggesting a potential novel role of these RNAs to the anti-bacterial cellular response.

The cytoplasmic IFN-induced lncRNA, $\operatorname{lnc}-\mathrm{Lsm} 3 b$, was also recently found to interact with viral RNA molecules to inactivate the well-studied PRR, RIG-I (retinoic acid-inducible gene-I) function towards the later stages of the innate response [63]. Structural motifs of this lncRNA were found to be essential for optimal RIG-I protein binding and the modulation of IFN type I production to regulate the innate response and maintain immune homeostasis.

The lncRNA ITPRIP-1 (IncITPRIP-1) was also shown to play a significant role in regulating innate immunity in response to viral infection. According to recent evidence by Xie et al. [103], IncITPRIP-1 interacts with the C-terminus of the melanoma differentiation-associated gene 5 (MDA5) to regulate the IFN signalling response. The study also demonstrated that hepatitis $\mathrm{C}$ virus (HCV) replication may be mediated by MDA5 and its interaction with IncITPRIP-1. MDA5 and IncITPRIP-1 expression levels were correlated, indicating a co-dependent working mechanism to regulate the innate immune response during viral invasion.

\section{Future Perspectives}

It is now clear that lncRNAs are central regulators of the production of inflammatory mediators associated with the activation of the innate immune response. However, little is still known regarding their role in myeloid cell proliferation/differentiation or other responses involved in pathogen clearance, including adhesion, chemotaxis, exocytosis, phagocytosis and antigen presentation. Furthermore, despite the increasing number of proteins that have been shown to mediated the actions of lncRNAs, little is known about the domains that are responsible for these lncRNA:protein interactions. This is important because it would permit the identification of functional lncRNA based on sequence and/or structure. To date, this process has been hindered by their cell/tissue specific expression and poor evolutionary conservation, with the majority being expressed exclusively in either human or mouse. However, there are a number of exceptions to this rule include IL7-AS [59], Inc-13 [76], MALAT1 [82,83] and FIRRE [89], that have been shown to be expressed and regulate the inflammatory response in both species, and detailed mechanistic analysis of these specific lncRNA could begin to reveal these domains. Finally, changes in lncRNA expression and the presence of polymorphisms are increasingly implicated in the development of disease, an observation that could make lncRNA novel drug targets for conditions such as autoimmune diseases, allergies, chronic inflammation and infection. 
Author Contributions: M.R.H. wrote the original article and designed the figures, M.A.L. wrote, revised and approved the final version of this review.

Funding: M.R.H. and M.A.L. are supported by the Biotechnology and Biological Sciences Research Council (BB/N015630/1).

Conflicts of Interest: The authors declare no conflicts of interest.

\section{References}

1. Mendell, J.T.; Sharifi, N.A.; Meyers, J.L.; Martinez-Murillo, F.; Dietz, H.C. Nonsense surveillance regulates expression of diverse classes of mammalian transcripts and mutes genomic noise. Nat. Genet. 2004, 36, 1073-1078. [CrossRef] [PubMed]

2. Gutschner, T.; Diederichs, S. The hallmarks of cancer: A long non-coding RNA point of view. RNA Biol. 2012, 9, 703-719. [CrossRef]

3. Okazaki, Y.; Furuno, M.; Kasukawa, T.; Adachi, J.; Bono, H.; Kondo, S.; Nikaido, I.; Osato, N.; Saito, R.; Suzuki, H.; et al. Analysis of the mouse transcriptome based on functional annotation of 60,770 full-length cDNAs. Nature 2002, 420, 563-573. [PubMed]

4. Gencode. GENCODE. Statistics about the Current GENCODE Release (version 29). 2019. Available online: https://www.gencodegenes.org/human/stats.html (accessed on 12 February 2019).

5. Pertea, M.; Salzberg, S.L. Between a chicken and a grape: Estimating the number of human genes. Genome Biol. 2010, 11, 206. [CrossRef] [PubMed]

6. Guttman, M.; Amit, I.; Garber, M.; French, C.; Lin, M.F.; Feldser, D.; Huarte, M.; Zuk, O.; Carey, B.W.; Cassady, J.P.; et al. Chromatin signature reveals over a thousand highly conserved large non-coding RNAs in mammals. Nature 2009, 458, 223-227. [CrossRef]

7. Englert, M.; Felis, M.; Junker, V.; Beier, H. Novel upstream and intragenic control elements for the RNA polymerase III-dependent transcription of human 7SL RNA genes. Biochimie 2004, 86, 867-874. [CrossRef]

8. Blythe, A.J.; Fox, A.H.; Bond, C.S. The ins and outs of lncRNA structure: How, why and what comes next? Biochim. Biophys. Acta 2016, 1859, 46-58. [CrossRef]

9. Necsulea, A.; Necsulea, A.; Kaessmann, H.; Kaessmann, H. Evolutionary dynamics of coding and non-coding transcriptomes. Nat. Rev. Genet. 2014, 15, 734-748. [CrossRef]

10. Esteller, M.; Esteller, M.; Esteller, M. Non-coding RNAs in human disease. Nat. Rev. Genet. 2011, 12, 861-874. [CrossRef] [PubMed]

11. Chen, X.; Yan, C.C.; Zhang, X.; You, Z.-H. Long non-coding RNAs and complex diseases: From experimental results to computational models. Brief. Bioinform. 2017, 18, 558-576. [CrossRef] [PubMed]

12. Hon, C.-C.; Ramilowski, J.A.; Harshbarger, J.; Bertin, N.; Rackham, O.J.L.; Gough, J.; Denisenko, E.; Schmeier, S.; Poulsen, T.M.; Severin, J.; et al. An atlas of human long non-coding RNAs with accurate 5' ends. Nature 2017, 543, 199-204. [CrossRef] [PubMed]

13. Derrien, T.; Johnson, R.; Bussotti, G.; Tanzer, A.; Djebali, S.; Tilgner, H.; Guernec, G.; Martin, D.; Merkel, A.; Knowles, D.G.; et al. The GENCODE v7 catalog of human long noncoding RNAs: Analysis of their gene structure, evolution, and expression. Genome Res. 2012, 22, 1775-1789. [CrossRef]

14. Natoli, G.; Andrau, J.-C. Noncoding transcription at enhancers: General principles and functional models. Annu. Rev. Genet. 2012, 46,1-19. [CrossRef] [PubMed]

15. Memczak, S.; Jens, M.; Elefsinioti, A.; Torti, F.; Krueger, J.; Rybak, A.; Maier, L.; Mackowiak, S.D.; Gregersen, L.H.; Munschauer, M.; et al. Circular RNAs are a large class of animal RNAs with regulatory potency. Nature 2013, 495, 333-338. [CrossRef]

16. Zhang, Y.; Yang, L.; Chen, L.-L. Life without A tail: New formats of long noncoding RNAs. Int. J. Biochem. Cell Biol. 2014, 54, 338-349. [CrossRef] [PubMed]

17. Ruiz-Orera, J.; Messeguer, X.; Subirana, J.A.; Alba, M.M. Long non-coding RNAs as a source of new peptides. Elife 2014, 3, e03523. [CrossRef] [PubMed]

18. Cabili, M.N.; Trapnell, C.; Goff, L.; Koziol, M.; Tazon-Vega, B.; Regev, A.; Rinn, J.L. Integrative annotation of human large intergenic noncoding RNAs reveals global properties and specific subclasses. Genes Dev. 2011, 25, 1915-1927. [CrossRef] [PubMed] 
19. Hezroni, H.; Koppstein, D.; Schwartz, M.G.; Avrutin, A.; Bartel, D.P.; Ulitsky, I. Principles of long noncoding RNA evolution derived from direct comparison of transcriptomes in 17 species. Cell Rep. 2015, 11, 1110-1122. [CrossRef]

20. Melé, M.; Mattioli, K.; Mallard, W.; Shechner, D.M.; Gerhardinger, C.; Rinn, J.L. Chromatin environment, transcriptional regulation, and splicing distinguish lincRNAs and mRNAs. Genome Res. 2017, 27, 27-37. [CrossRef]

21. Ransohoff, J.D.; Wei, Y.; Khavari, P.A. The functions and unique features of long intergenic non-coding RNA. Nat. Rev. Mol. Cell Biol. 2018, 19, 143-157. [CrossRef]

22. Ulitsky, I.; Bartel, D.P. lincRNAs: Genomics, evolution, and mechanisms. Cell 2013, 154, 26-46. [CrossRef]

23. Gloss, B.S.; Dinger, M.E. The specificity of long noncoding RNA expression. Biochim. Biophys. Acta 2016, 1859, 16-22. [CrossRef] [PubMed]

24. Rands, C.M.; Meader, S.; Ponting, C.P.; Lunter, G. 8.2\% of the Human genome is constrained: Variation in rates of turnover across functional element classes in the human lineage. PLoS Genet. 2014, 10, e1004525. [CrossRef]

25. Guttman, M.; Garber, M.; Levin, J.Z.; Donaghey, J.; Robinson, J.; Adiconis, X.; Fan, L.; Koziol, M.J.; Gnirke, A.; Nusbaum, C.; et al. Ab initio reconstruction of cell type-specific transcriptomes in mouse reveals the conserved multi-exonic structure of lincRNAs. Nat. Biotechnol. 2010, 28, 503-510. [CrossRef]

26. Ulitsky, I.; Shkumatava, A.; Jan, C.H.; Sive, H.; Bartel, D.P. Conserved function of lincRNAs in vertebrate embryonic development despite rapid sequence evolution. Cell 2011, 147, 1537-1550. [CrossRef]

27. Johnsson, P.; Lipovich, L.; Grandér, D.; Morris, K.V. Evolutionary conservation of long non-coding RNAs; sequence, structure, function. Biochim. Biophys. Acta 2014, 1840, 1063-1071. [CrossRef]

28. Djebali, S.; Davis, C.A.; Merkel, A.; Dobin, A.; Lassmann, T.; Mortazavi, A.; Tanzer, A.; Lagarde, J.; Lin, W.; Schlesinger, F.; et al. Landscape of transcription in human cells. Nature 2012, 489, 101-108. [CrossRef] [PubMed]

29. Clemson, C.M.; Hutchinson, J.N.; Sara, S.A.; Ensminger, A.W.; Fox, A.H.; Chess, A.; Lawrence, J.B. An architectural role for a nuclear noncoding RNA: NEAT1 RNA is essential for the structure of paraspeckles. Mol. Cell 2009, 33, 717-726. [CrossRef]

30. Tripathi, V.; Ellis, J.D.; Shen, Z.; Song, D.Y.; Pan, Q.; Watt, A.T.; Freier, S.M.; Bennett, C.F.; Sharma, A.; Bubulya, P.A.; et al. The nuclear-retained noncoding RNA MALAT1 regulates alternative splicing by modulating SR splicing factor phosphorylation. Mol. Cell 2010, 39, 925-938. [CrossRef] [PubMed]

31. Brown, C.J.; Hendrich, B.D.; Rupert, J.L.; Lafrenière, R.G.; Xing, Y.; Lawrence, J.; Willard, H.F. The human XIST gene: Analysis of a $17 \mathrm{~kb}$ inactive X-specific RNA that contains conserved repeats and is highly localized within the nucleus. Cell 1992, 71, 527-542. [CrossRef]

32. Rashid, F.; Shah, A.; Shan, G. Long Non-coding RNAs in the Cytoplasm. Genom. Proteom. Bioinform. 2016, 14, 73-80. [CrossRef] [PubMed]

33. Van Heesch, S.; van Iterson, M.; Jacobi, J.; Boymans, S.; Essers, P.B.; de Bruijn, E.; Hao, W.; MacInnes, A.W.; Cuppen, E.; Simonis, M. Extensive localization of long noncoding RNAs to the cytosol and mono- and polyribosomal complexes. Genome Biol. 2014, 15, R6. [CrossRef]

34. Ingolia, N.T.; Ingolia, N.T.; Lareau, L.F.; Lareau, L.F.; Weissman, J.S.; Weissman, J.S. Ribosome profiling of mouse embryonic stem cells reveals the complexity and dynamics of mammalian proteomes. Cell 2011, 147, 789-802. [CrossRef]

35. Quinn, J.J.; Chang, H.Y. Unique features of long non-coding RNA biogenesis and function. Nat. Rev. Genet. 2016, 17, 47-62. [CrossRef]

36. Kung, J.T.Y.; Colognori, D.; Lee, J.T. Long noncoding RNAs: Past, present, and future. Genetics 2013, 193, 651-669. [CrossRef] [PubMed]

37. Magistri, M.; Faghihi, M.A.; Laurent, G.S.; Wahlestedt, C. Regulation of chromatin structure by long noncoding RNAs: Focus on natural antisense transcripts. Trends Genet. 2012, 28, 389-396. [CrossRef]

38. Faghihi, M.A.; Wahlestedt, C. Regulatory roles of natural antisense transcripts. Nat. Rev. Mol. Cell Biol. 2009, 10, 637-643. [CrossRef] [PubMed]

39. Villegas, V.E.; Zaphiropoulos, P.G. Neighboring gene regulation by antisense long non-coding RNAs. Int. J. Mol. Sci. 2015, 16, 3251-3266. [CrossRef]

40. Kim, T.-K.; Hemberg, M.; Gray, J.M.; Costa, A.M.; Bear, D.M.; Wu, J.; Harmin, D.A.; Laptewicz, M.; Barbara-Haley, K.; Kuersten, S.; et al. Widespread transcription at neuronal activity-regulated enhancers. Nature 2010, 465, 182-187. [CrossRef] 
41. Chen, H.; Du, G.; Song, X.; Li, L. Non-coding Transcripts from Enhancers: New Insights into Enhancer Activity and Gene Expression Regulation. Genom. Proteom. Bioinform. 2017, 15, 201-207. [CrossRef]

42. Liu, F. Enhancer-derived RNA: A Primer. Genom. Proteom. Bioinform. 2017, 15, 196-200. [CrossRef] [PubMed]

43. Zhang, Y.; Zhang, X.-O.; Chen, T.; Xiang, J.-F.; Yin, Q.-F.; Xing, Y.-H.; Zhu, S.; Yang, L.; Chen, L.-L. Circular intronic long noncoding RNAs. Mol. Cell 2013, 51, 792-806. [CrossRef] [PubMed]

44. Ayupe, A.C.; Tahira, A.C.; Camargo, L.; Beckedorff, F.C.; Verjovski-Almeida, S.; Reis, E.M. Global analysis of biogenesis, stability and sub-cellular localization of lncRNAs mapping to intragenic regions of the human genome. RNA Biol. 2015, 12, 877-892. [CrossRef] [PubMed]

45. Boivin, V.; Deschamps-Francoeur, G.; Scott, M.S. Protein coding genes as hosts for noncoding RNA expression. Semin. Cell Dev. Biol. 2018, 75, 3-12. [CrossRef]

46. Ebert, M.S.; Neilson, J.R.; Sharp, P.A. MicroRNA sponges: Competitive inhibitors of small RNAs in mammalian cells. Nat. Methods 2007, 4, 721-726. [CrossRef]

47. Hansen, T.B.; Wiklund, E.D.; Bramsen, J.B.; Villadsen, S.B.; Statham, A.L.; Clark, S.J.; Kjems, J. miRNA-dependent gene silencing involving Ago2-mediated cleavage of a circular antisense RNA. EMBO J. 2011, 30, 4414-4422. [CrossRef]

48. Jeck, W.R.; Sorrentino, J.A.; Wang, K.; Slevin, M.K.; Burd, C.E.; Liu, J.; Marzluff, W.F.; Sharpless, N.E. Circular RNAs are abundant, conserved, and associated with ALU repeats. RNA 2013, 19, 141-157. [CrossRef]

49. Hansen, T.B.; Jensen, T.I.; Clausen, B.H.; Bramsen, J.B.; Finsen, B.; Damgaard, C.K.; Kjems, J. Natural RNA circles function as efficient microRNA sponges. Nature 2013, 495, 384-388. [CrossRef] [PubMed]

50. Balakirev, E.S.; Ayala, F.J. Pseudogenes: Are They 'Junk' or Functional DNA? Annu. Rev. Genet. 2003, 37, $123-151$. [CrossRef] [PubMed]

51. Pink, R.C.; Wicks, K.; Caley, D.P.; Punch, E.K.; Jacobs, L.; Carter, D.R.F. Pseudogenes: Pseudo-functional or key regulators in health and disease? RNA 2011, 17, 792-798. [CrossRef] [PubMed]

52. Li, W.; Yang, W.; Wang, X.-J. Pseudogenes: Pseudo or real functional elements? J. Genet. Genom. 2013, 40, $171-177$. [CrossRef]

53. Gupta, R.A.; Shah, N.; Wang, K.C.; Kim, J.; Horlings, H.M.; Wong, D.J.; Tsai, M.-C.; Hung, T.; Argani, P.; Rinn, J.L.; et al. Long non-coding RNA HOTAIR reprograms chromatin state to promote cancer metastasis. Nature 2010, 464, 1071-1076. [CrossRef] [PubMed]

54. Cerase, A.; Pintacuda, G.; Tattermusch, A.; Avner, P. Xist localization and function: New insights from multiple levels. Genome Biol. 2015, 16, 166. [CrossRef] [PubMed]

55. Raveh, E.; Matouk, I.J.; Gilon, M.; Hochberg, A. The H19 Long non-coding RNA in cancer initiation, progression and metastasis-A proposed unifying theory. Mol. Cancer 2015, 14, 184. [CrossRef] [PubMed]

56. Zhang, K.; Shi, Z.-M.; Chang, Y.-N.; Hu, Z.-M.; Qi, H.-X.; Hong, W. The ways of action of long non-coding RNAs in cytoplasm and nucleus. Gene 2014, 547, 1-9. [CrossRef]

57. Hadjicharalambous, M.R.; Roux, B.T.; Csomor, E.; Feghali-Bostwick, C.A.; Murray, L.A.; Clarke, D.L.; Lindsay, M.A. Long intergenic non-coding RNAs regulate human lung fibroblast function: Implications for idiopathic pulmonary fibrosis. Sci. Rep. 2019, 9, 1-15. [CrossRef]

58. Pearson, M.J.; Philp, A.M.; Heward, J.A.; Roux, B.T.; Walsh, D.A.; Davis, E.T.; Lindsay, M.A.; Jones, S.W. Long Intergenic Noncoding RNAs Mediate the Human Chondrocyte Inflammatory Response and Are Differentially Expressed in Osteoarthritis Cartilage. Arthritis Rheumatol. 2016, 68, 845-856. [CrossRef] [PubMed]

59. Roux, B.T.; Heward, J.A.; Donnelly, L.E.; Jones, S.W.; Lindsay, M.A. Catalog of Differentially Expressed Long Non-Coding RNA following Activation of Human and Mouse Innate Immune Response. Front. Immunol. 2017, 8, 1038. [CrossRef] [PubMed]

60. Hadjicharalambous, M.R.; Roux, B.T.; Feghali-Bostwick, C.A.; Murray, L.A.; Clarke, D.L.; Lindsay, M.A. Long Non-coding RNAs Are Central Regulators of the IL-1 $\beta$-Induced Inflammatory Response in Normal and Idiopathic Pulmonary Lung Fibroblasts. Front. Immunol. 2018, 9, 2906. [CrossRef]

61. Krawczyk, M.; Emerson, B.M. p50-associated COX-2 extragenic RNA (PACER) activates COX-2 gene expression by occluding repressive NF- $\mathrm{B}$ complexes. Elife 2014, 3, e01776. [CrossRef]

62. Tong, X.; Gu, P.-C.; Xu, S.-Z.; Lin, X.-J. Long non-coding RNA-DANCR in human circulating monocytes: A potential biomarker associated with postmenopausal osteoporosis. Biosci. Biotechnol. Biochem. 2015, 79, 732-737. [CrossRef] [PubMed] 
63. Jiang, M.; Zhang, S.; Yang, Z.; Lin, H.; Zhu, J.; Liu, L.; Wang, W.; Liu, S.; Liu, W.; Ma, Y.; et al. Self-Recognition of an Inducible Host lncRNA by RIG-I Feedback Restricts Innate Immune Response. Cell 2018, 173, 906-919.e13. [CrossRef] [PubMed]

64. Kotzin, J.J.; Spencer, S.P.; McCright, S.J.; Kumar, D.B.U.; Collet, M.A.; Mowel, W.K.; Elliott, E.N.; Uyar, A.; Makiya, M.A.; Dunagin, M.C.; et al. The long non-coding RNA Morrbid regulates Bim and short-lived myeloid cell lifespan. Nature 2016, 537, 239-243. [CrossRef]

65. Covarrubias, S.; Robinson, E.K.; Shapleigh, B.; Vollmers, A.; Katzman, S.; Hanley, N.; Fong, N.; McManus, M.T.; Carpenter, S. CRISPR/Cas-based screening of long non-coding RNAs (lncRNAs) in macrophages with an NF- $\mathrm{BB}$ reporter. J. Biol. Chem. 2017, 292, 20911-20920. [CrossRef]

66. Cao, H.; Wahlestedt, C.; Kapranov, P. Strategies to Annotate and Characterize Long Noncoding RNAs: Advantages and Pitfalls. Trends Genet. 2018, 34, 704-721. [CrossRef] [PubMed]

67. Gasteiger, G.; D'Osualdo, A.; Schubert, D.A.; Weber, A.; Bruscia, E.M.; Hartl, D. Cellular Innate Immunity: An Old Game with New Players. J. Innate Immun. 2017, 9, 111-125. [CrossRef] [PubMed]

68. Kondo, M. Lymphoid and myeloid lineage commitment in multipotent hematopoietic progenitors. Immunol. Rev. 2010, 238, 37-46. [CrossRef] [PubMed]

69. Venkatraman, A.; He, X.C.; Thorvaldsen, J.L.; Sugimura, R.; Perry, J.M.; Tao, F.; Zhao, M.; Christenson, M.K.; Sanchez, R.; Yu, J.Y.; et al. Maternal imprinting at the H19-Igf2 locus maintains adult haematopoietic stem cell quiescence. Nature 2013, 500, 345-349. [CrossRef] [PubMed]

70. Luo, M.; Jeong, M.; Sun, D.; Park, H.J.; Rodriguez, B.A.T.; Xia, Z.; Yang, L.; Zhang, X.; Sheng, K.; Darlington, G.J.; et al. Long non-coding RNAs control hematopoietic stem cell function. Cell Stem Cell 2015, 16, 426-438. [CrossRef]

71. Geissmann, F.; Manz, M.G.; Jung, S.; Sieweke, M.H.; Merad, M.; Ley, K. Development of monocytes, macrophages, and dendritic cells. Science 2010, 327, 656-661. [CrossRef] [PubMed]

72. Cui, H.; Xie, N.; Tan, Z.; Banerjee, S.; Thannickal, V.J.; Abraham, E.; Liu, G. The human long noncoding RNA lnc-IL7R regulates the inflammatory response. Eur. J. Immunol. 2014, 44, 2085-2095. [CrossRef] [PubMed]

73. Mariotti, B.; Servaas, N.H.; Rossato, M.; Tamassia, N.; Cassatella, M.A.; Cossu, M.; Beretta, L.; van der Kroef, M.; Radstake, T.R.D.J.; Bazzoni, F. The Long Non-coding RNA NRIR Drives IFN-Response in Monocytes: Implication for Systemic Sclerosis. Front Immunol. 2019, 10, 100. [CrossRef] [PubMed]

74. Dave, R.K.; Dinger, M.E.; Andrew, M.; Askarian-Amiri, M.; Hume, D.A.; Kellie, S. Regulated expression of PTPRJ/CD148 and an antisense long noncoding RNA in macrophages by proinflammatory stimuli. PLoS ONE 2013, 8, e68306. [CrossRef] [PubMed]

75. Du, M.; Yuan, L.; Tan, X.; Huang, D.; Wang, X.; Zheng, Z.; Mao, X.; Li, X.; Yang, L.; Huang, K.; et al. The LPS-inducible lncRNA Mirt2 is a negative regulator of inflammation. Nat. Commun. 2017, 8, 2049. [CrossRef] [PubMed]

76. Castellanos-Rubio, A.; Fernandez-Jimenez, N.; Kratchmarov, R.; Luo, X.; Bhagat, G.; Green, P.H.R.; Schneider, R.; Kiledjian, M.; Bilbao, J.R.; Ghosh, S. A long noncoding RNA associated with susceptibility to celiac disease. Science 2016, 352, 91-95. [CrossRef]

77. Chan, J.; Atianand, M.; Jiang, Z.; Carpenter, S.; Aiello, D.; Elling, R.; Fitzgerald, K.A.; Caffrey, D.R. Cutting Edge: A Natural Antisense Transcript, AS-IL1 $\alpha$, Controls Inducible Transcription of the Proinflammatory Cytokine IL-1 $\alpha$. J. Immunol. 2015, 195, 1359-1363. [CrossRef]

78. Carpenter, S.; Aiello, D.; Atianand, M.K.; Ricci, E.P.; Gandhi, P.; Hall, L.L.; Byron, M.; Monks, B.; Henry-Bezy, M.; Lawrence, J.B.; et al. A Long Noncoding RNA Mediates Both Activation and Repression of Immune Response Genes. Science 2013, 341, 789-792. [CrossRef]

79. Hu, G.; Gong, A.-Y.; Wang, Y.; Ma, S.; Chen, X.; Chen, J.; Su, C.-J.; Shibata, A.; Strauss-Soukup, J.K.; Drescher, K.M.; et al. LincRNA-Cox2 Promotes Late Inflammatory Gene Transcription in Macrophages through Modulating SWI/SNF-Mediated Chromatin Remodeling. J. Immunol. 2016, 196, 2799-2808. [CrossRef]

80. Xue, Z.; Zhang, Z.; Liu, H.; Li, W.; Guo, X.; Zhang, Z.; Liu, Y.; Jia, L.; Li, Y.; Ren, Y.; et al. lincRNA-Cox2 regulates NLRP3 inflammasome and autophagy mediated neuroinflammation. Cell Death Differ. 2019, 26, 130-145. [CrossRef]

81. Elling, R.; Robinson, E.K.; Shapleigh, B.; Liapis, S.C.; Covarrubias, S.; Katzman, S.; Groff, A.F.; Jiang, Z.; Agarwal, S.; Motwani, M.; et al. Genetic Models Reveal cis and trans Immune-Regulatory Activities for lincRNA-Cox2. Cell Rep. 2018, 25, 1511-1524.e6. [CrossRef] 
82. Zhao, G.; Su, Z.; Song, D.; Mao, Y.; Mao, X. The long noncoding RNA MALAT1 regulates the lipopolysaccharide-induced inflammatory response through its interaction with NF-кB. FEBS Lett. 2016, 590, 2884-2895. [CrossRef] [PubMed]

83. Cui, H.; Banerjee, S.; Guo, S.; Xie, N.; Ge, J.; Jiang, D.; Zörnig, M.; Thannickal, V.J.; Liu, G. Long noncoding RNA Malat1 regulates differential activation of macrophages and response to lung injury. JCI Insight 2019, 4, 176. [CrossRef] [PubMed]

84. Li, Z.; Li, Z.; Chao, T.-C.; Chao, T.C.; Chang, K.Y.; Chang, K.-Y.; Lin, N.; Lin, N.; Patil, V.S.; Patil, V.S.; et al. The long noncoding RNA THRIL regulates TNF $\alpha$ expression through its interaction with hnRNPL. Proc. Natl. Acad. Sci. USA 2014, 111, 1002-1007. [CrossRef]

85. Iott, N.E.I.; Heward, J.A.; Roux, B.; Tsitsiou, E.; Fenwick, P.S.; Lenzi, L.; Goodhead, I.; Hertz-Fowler, C.; Heger, A.; Hall, N.; et al. Long non-coding RNAs and enhancer RNAs regulate the lipopolysaccharide-induced inflammatory response in human monocytes. Nat. Commun. 2014, 5, 3979.

86. Atianand, M.K.; Hu, W.; Satpathy, A.T.; Shen, Y.; Ricci, E.P.; Alvarez-Dominguez, J.R.; Bhatta, A.; Schattgen, S.A.; McGowan, J.D.; Blin, J.; et al. A Long Noncoding RNA lincRNA-EPS Acts as a Transcriptional Brake to Restrain Inflammation. Cell 2016, 165, 1672-1685. [CrossRef] [PubMed]

87. Ma, S.; Ming, Z.; Gong, A.-Y.; Wang, Y.; Chen, X.; Hu, G.; Zhou, R.; Shibata, A.; Swanson, P.C.; Chen, X.-M. A long noncoding RNA, lincRNA-Tnfaip3, acts as a coregulator of NF- $\mathrm{kB}$ to modulate inflammatory gene transcription in mouse macrophages. FASEB J. 2017, 31, 1215-1225. [CrossRef]

88. Yang, C.-A.; Li, J.-P.; Yen, J.-C.; Lai, I.-L.; Ho, Y.-C.; Chen, Y.-C.; Lan, J.-L.; Chang, J.-G. IncRNA NTT/PBOV1 Axis Promotes Monocyte Differentiation and Is Elevated in Rheumatoid Arthritis. Int. J. Mol. Sci. 2018, 19, 2806. [CrossRef] [PubMed]

89. Lu, Y.; Liu, X.; Xie, M.; Liu, M.; Ye, M.; Li, M.; Chen, X.-M.; Li, X.; Zhou, R. The NF-kB-Responsive Long Noncoding RNA FIRRE Regulates Posttranscriptional Regulation of Inflammatory Gene Expression through Interacting with hnRNPU. J. Immunol. 2017, 199, 3571-3582. [CrossRef]

90. Hu, W.; Yuan, B.; Flygare, J.; Lodish, H.F. Long noncoding RNA-mediated anti-apoptotic activity in murine erythroid terminal differentiation. Genes Dev. 2011, 25, 2573-2578. [CrossRef]

91. Buenrostro, J.D.; Giresi, P.G.; Zaba, L.C.; Chang, H.Y.; Greenleaf, W.J. Transposition of native chromatin for fast and sensitive epigenomic profiling of open chromatin, DNA-binding proteins and nucleosome position. Nat. Methods 2013, 10, 1213-1218. [CrossRef]

92. Clark, G.J.; Angel, N.; Kato, M.; López, J.A.; MacDonald, K.; Vuckovic, S.; Hart, D.N. The role of dendritic cells in the innate immune system. Microbes Infect. 2000, 2, 257-272. [CrossRef]

93. Wu, J.; Zhang, H.; Zheng, Y.; Jin, X.; Liu, M.; Li, S.; Zhao, Q.; Liu, X.; Wang, Y.; Shi, M.; et al. The Long Noncoding RNA MALAT1 Induces Tolerogenic Dendritic Cells and Regulatory T Cells via miR155/Dendritic Cell-Specific Intercellular Adhesion Molecule-3 Grabbing Nonintegrin/IL10 Axis. Front. Immunol. 2018, 9, 1847. [CrossRef] [PubMed]

94. Wang, P.; Xue, Y.; Han, Y.; Lin, L.; Wu, C.; Xu, S.; Jiang, Z.; Xu, J.; Liu, Q.; Cao, X. The STAT3-binding long noncoding RNA lnc-DC controls human dendritic cell differentiation. Science 2014, 344, 310-313. [CrossRef] [PubMed]

95. Bautista-Hernández, L.A.; Gómez-Olivares, J.L.; Buentello-Volante, B.; Lucio, V.M.B. Fibroblasts: The Unknown Sentinels Eliciting Immune Responses Against Microorganisms. Eur. J. Microbiol. Immunol. 2017, 7, 151-157. [CrossRef] [PubMed]

96. Rapicavoli, N.A.; Qu, K.; Zhang, J.; Mikhail, M.; Laberge, R.-M.; Chang, H.Y. A mammalian pseudogene lncRNA at the interface of inflammation and anti-inflammatory therapeutics. Elife 2013, 2, e00762. [CrossRef] [PubMed]

97. Zgheib, C.; Hodges, M.M.; Hu, J.; Liechty, K.W.; Xu, J. Long non-coding RNA Lethe regulates hyperglycemia-induced reactive oxygen species production in macrophages. PLoS ONE 2017, 12, e0177453. [CrossRef] [PubMed]

98. Schleimer, R.P.; Kato, A.; Kern, R.; Kuperman, D.; Avila, P.C. Epithelium: At the interface of innate and adaptive immune responses. J. Allergy Clin. Immunol. 2007, 120, 1279-1284. [CrossRef]

99. Tong, Q.; Gong, A.-Y.; Zhang, X.-T.; Lin, C.; Ma, S.; Chen, J.; Hu, G.; Chen, X.-M. LincRNA-Cox2 modulates TNF- $\alpha$-induced transcription of Il12b gene in intestinal epithelial cells through regulation of Mi-2/NuRD-mediated epigenetic histone modifications. FASEB J. 2016, 30, 1187-1197. [CrossRef] [PubMed] 
100. Imamura, K.; Imamachi, N.; Akizuki, G.; Kumakura, M.; Kawaguchi, A.; Nagata, K.; Kato, A.; Kawaguchi, Y.; Sato, H.; Yoneda, M.; et al. Long noncoding RNA NEAT1-dependent SFPQ relocation from promoter region to paraspeckle mediates IL8 expression upon immune stimuli. Mol. Cell 2014, 53, 393-406. [CrossRef] [PubMed]

101. Morchikh, M.; Cribier, A.; Raffel, R.; Amraoui, S.; Cau, J.; Severac, D.; Dubois, E.; Schwartz, O.; Bennasser, Y.; Benkirane, M. HEXIM1 and NEAT1 Long Non-coding RNA Form a Multi-subunit Complex that Regulates DNA-Mediated Innate Immune Response. Mol. Cell 2017, 67, 387-399.e5. [CrossRef]

102. Imamura, K.; Takaya, A.; Ishida, Y.I.; Fukuoka, Y.; Taya, T.; Nakaki, R.; Kakeda, M.; Imamachi, N.; Sato, A.; Yamada, T.; et al. Diminished nuclear RNA decay upon Salmonella infection upregulates antibacterial noncoding RNAs. EMBO J. 2018, 37, e97723. [CrossRef] [PubMed]

103. Xie, Q.; Chen, S.; Tian, R.; Huang, X.; Deng, R.; Xue, B.; Qin, Y.; Xu, Y.; Wang, J.; Guo, M.; et al. Long Noncoding RNA ITPRIP-1 Positively Regulates the Innate Immune Response through Promotion of Oligomerization and Activation of MDA5. J. Virol. 2018, 92, 146. [CrossRef] [PubMed]

(C) 2019 by the authors. Licensee MDPI, Basel, Switzerland. This article is an open access article distributed under the terms and conditions of the Creative Commons Attribution (CC BY) license (http://creativecommons.org/licenses/by/4.0/). 